\title{
Selection of snap beans progenies to improve physiological quality of seeds
}

\section{Seleção de progênies de feijão vagem visando a qualidade fisiológica de sementes}

\author{
Silvia Sanielle Costa de Oliveira ${ }^{1 *}$; Eduardo Santana Bueno²; Daline Benites \\ Bottega $^{1}$; Vanessa de Fátima Grah Ponciano ${ }^{3}$; Sihélio Júlio Silva Cruz ${ }^{1}$
}

\section{Highlights:}

A study with snap bean to improve production technologies.

Evaluate tests for selecting populations with superior physiological quality.

Estimate the genetic gain for the next progeny selection cycle.

\begin{abstract}
Research on snap bean seed production is essential for this crop to compete against other species that have better production technologies. This study aimed to select a physiological quality evaluation test for snap beans to improve progeny selection strategies. The experiment was conducted in the Seed Analysis Laboratory at the Federal Institute of Goiano, campus Iporá-GO. Seed from thirteen progenies were evaluated for physiological quality from a breeding program conducted by the genetic breeding department of the State University of Goiás, campus Ipameri. Seeds were evaluated for moisture content, thousand-seed weight, biometry (length, width, and thickness), germination, seedling vigor classification, length and seedling dry mass, emergence in the field, and emergence speed index of seedlings in the field. The genetic variability in the evaluated characteristics indicated that genetic breeding can contribute to a better performance in snap bean seed physiological quality. The germination test, vigor classification, emergence, and emergence speed index of seedlings can be used to design strategies for snap bean population selection that produces more productive seeds.
\end{abstract}

Key words: Gain by selection. Heritability. Phaseolus vulgaris. Seedling emergence.

\section{Resumo}

Pesquisas referentes à produção de sementes de feijão-vagem são essenciais para que esta cultura se estabeleça frente a outras espécies que possuem tecnologia de produção aprimorada. Assim, objetivouse com este trabalho selecionar testes de avaliação da qualidade fisiológica de sementes de feijão-vagem visando a definição de estratégias de seleção de progênies. $\mathrm{O}$ experimento foi realizado no Laboratório de Análise de Sementes do Instituto Federal Goiano, campus Iporá. Foram avaliadas a qualidade fisiológica das sementes de 13 progênies, pertencentes ao programa de melhoramento realizado pela área de melhoramento genético da Universidade Estadual de Goiás, campus Ipameri. Foram determinados

1 Profs. Drs., Curso de Graduação em Agronomia e Programa de Pós-Graduação em Bioenergia e Grãos, Instituto Federal Goiano, IF Goiano, Iporá, GO, Brasil. E-mail: silvia.oliveira@ifgoiano.edu.br; daline.bottega@ifgoiano.edu.br; sihelio.cruz@ifgoiano. edu.br

2 Discente do Curso de Graduação em Agronomia, IF Goiano, Iporá, GO, Brasil. E-mail: eduradosantana.agro@outlook.com

3 Prof ${ }^{a}$ Dra $^{a}$, Curso de Graduação em Agronomia, IF Goiano, Iporá, GO, Brasil. E-mail: vanessa.grah@ifgoiano.edu.br

* Author for correspondence 
o teor de água, massa de mil sementes, biometria de sementes (comprimento, largura e espessura), germinação, classificação do vigor de plântulas, comprimento e massa seca das plântulas, teste de emergência de plântulas e índice de velocidade de emergência de plântulas em condições de campo. A variabilidade genética presente nos caracteres avaliados indica que o melhoramento genético pode contribuir significativamente para a melhoria da qualidade fisiológica das sementes de feijão-vagem. Os testes de germinação, classificação do vigor, emergência de plântulas e índice de velocidade de plântulas podem ser utilizados para delinear estratégias de seleção de populações de feijão-vagem que produzam sementes mais vigorosas.

Palavras-chave: Emergência de plântulas. Ganho por seleção. Herdabilidade. Phaseolus vulgaris.

\section{Introduction}

The snap bean is an improved type of common bean (Phaseolus vulgaris L.) with features such as fiber-free and tender pods, light green coloration, and a straight shape. Snap beans have a length that varies between 0.15 to $0.18 \mathrm{~m}$ (Krause, Rodrigues, $\&$ Leal, 2012). Its commercial exploitation aims at the complete use of the pods, which are consumed fresh or processed (A. P. Oliveira, Tavares Sobrinho, $\&$ Sousa, 2003). The snap bean differs from other beans in that its entire pod can be consumed before the seeds inside have fully matured, making the snap bean is rich in dietary fiber and an appreciable quantity of vitamins B1 and B2 (Matos, 2010).

Snap bean has great economic and social importance in Brazil. It is consumed in several countries and 6.5 million tons of snap beans are produced per year (Food and Agriculture Organization [FAO], 2010), with China being the main producer, followed by Indonesia and Turkey. In Brazil, snap beans are the sixth most-produced vegetable by volume, with 56 thousand tons grown per year and a consumption of $0.7 \mathrm{~kg}$ per person per year (Centrais de Abastecimento do Estado do Rio de Janeiro [CEASA], 2010). The snap bean stands out among the ten most consumed fresh vegetables in the state of Goiás; in 2002, the volume of pods marketed in CEASAs of Goiás reached 5,291 tons, with $94.5 \%$ produced in the state by small farms (Peixoto, Moraes, Monteiro, \& Thung, 2001). Seeds are a key input in the productive process and their quality is an indispensable factor in the production of a uniform product and the success of a productive farm.
The use of seeds with high physiological potential is essential to obtaining economically significant crops. Thus, research that focuses on the production of snap bean seeds is essential for this crop to establish itself from other species that have more improved production technology. Because the seeds are the genetic features vehicle for the implantation of any crop, this input is the primary concern in providing a uniform and productive crop (A. P. Oliveira et al., 2003).

Plants with good agronomic features can be eliminated during selection in breeding programs because of the poor quality of their seeds, or the genotypes can be removed by the market before sale. Therefore, it is important to obtain efficient, fast, practical, and economical methods of analysis that will assist breeders in the selection of snap bean populations with superior physiological seeds. The quality of seeds is influenced by the genotype, so it is imperative to evaluate their quality to facilitate the breeder's ability to choose progenies of snap bean cultivars that will bring more security to the seed production process with the desirable genetic gain. Research evaluating germination and seed vigor (e.g., germination first count, germination, accelerated aging tests, emergence of seedlings in the field, and storage potential) has indicated that breeding programs combined with selection methods based on the index theory can improve the quality of seeds (Maia, Silva, Ramalho, \& Abreu, 2011; Vasconcelos, Reis, Sediyama, \& Cruz, 2012; Martins; Silva; Machado, 2014; S. S. C. Oliveira, Martins, Cruz, \& Silva, 2014; S. S. C. Oliveira, Pereira, Lopes, \& Torres, 2017). 
Studies of genetic breeding in plants that aim to improve physiological qualities of bean seeds (Maia et al., 2011; Mambrin, Ribeiro, Henning, Henning \& Bokert, 2015), soybean (Vasconcelos et al., 2012; Martins, Unêda-Trevisoli, Vitti Môro, \& Vieira, 2016), carrot (Martins et al., 2014), and forage turnip (S. S. C. Oliveira et al., 2014; S. S. C. Oliveira et al., 2017) to provide high heritability ( $>70 \%$ ) and genetic variability. Therefore, the use of simple breeding methods could improve the quality of snap bean seeds, selection of progenies with longer-lived seeds, and greater seedling emergence in the field. This study aimed to select a physiological quality evaluation test for snap beans to improve progeny selection strategies.

\section{Materials and Methods}

The experiment was conducted at the Laboratory of Seed Analysis at the Federal Institute Goiano, Iporá - Goiás, Brazil. Thirteen snap bean progenies were provided by the State University of Goiás, Ipameri-GO and included MR malina, Tender Green, Haf 46, Amarelo Japonês, Napoli, Delinel, Red Provided, Branco Japonês, Commodose Improved, Contender, Jade, Strike, and Espada Bush.

Which one of the seeds progenies were cleaned and subjected to the following evaluations:

Moisture content (MC) test was conducted before the other tests, using two subsamples of 20 seeds from each lot using by the oven method at $105 \pm 3$ ${ }^{\circ} \mathrm{C}$ for $24 \mathrm{~h}$, Ministério da Agricultura e Reforma Agrária (2009).

Thousand-seed weight (TSW) was based on eight 100 seed samples from each progeny Ministério da Agricultura e Reforma Agrária 2009).

Seed biometrics (BS) was based on eight subsamples of 100 seeds per progeny in which the length, width, and thickness were evaluated (Ministério da Agricultura e Reforma Agrária, 2009).
Germination test $(G)$ was conducted with four 50 -seed samples. The seeds were placed on top of filter paper, wetted with distilled water at an amount corresponding to 2.5 times the weight of the substratum, and then placed inside transparent plastic boxes $(11.0 \times 11.0 \times 3.5 \mathrm{~cm})$, which placed in a germinator at $25^{\circ} \mathrm{C}$. Seedling counts were made 5 and 9 days after sowing (Ministério da Agricultura e Reforma Agrária, 2009).

Classification of seedling vigor (CSV) was conducted by separating the normal and welldeveloped seedlings that were then counted and classified as "strong" (with high vigor). In the final germination count, the remaining seedlings were evaluated as normal and abnormal. The normal was classified as "strong" or "weak." Weak normal seedlings had problems in their structure or injury, but at levels that were insufficient to characterize them as abnormal (Nakagawa, 1999). Only strong normal seedlings were used for further evaluation.

Length seedling (LS) and seedling dry mass (DM): At the end of the germination count, the total length of the normal seedlings of each replicate was measured with a ruler. After measuring the length, the seedlings were packed in Kraft paper bags and placed in an oven without removing the cotyledons, according to the method described by Nakagawa (1999). After drying, the samples were removed from the oven and weighed with a precision balance.

Emergence of seedlings in the field (ESF) was conducted in beds in the field in Iporá, GO. The plots consisted of two replicate rows $(1.5 \mathrm{~m}$ furrows) spaced $0.2 \mathrm{~m}$ apart, with 50 seeds sown per furrow at a depth of $0.02-0.03 \mathrm{~m}$. Seedlings were counted on the fifth and ninth days after sowing. A thermometer installed near the beds was used to measure the maximum and minimum temperatures for the test period. The temperature ranged from 24 - $27^{\circ} \mathrm{C}$. The plots were irrigated daily to maintain soil moisture at the appropriate level.

Emergence speed index of seedlings in the field (ESI) was calculated from the data of daily counts 
of emerged seedlings using the formula described by Maguire (1962).

The experimental design was completely randomized, with four replications. The experimental data were subjected to analysis of variance using the Genes-UFV app (Cruz, 2001). The following parameters were evaluated:

Large sense heritability based on plot means

$$
h^{2}=\frac{\widehat{\sigma}_{g}{ }^{2}}{\widehat{\sigma}_{f}{ }^{2}}
$$

Genetic coefficient of variation

$$
C V_{g}=\frac{\left(100 \sqrt{\widehat{\sigma}^{2}}\right)}{\widehat{m}} ;
$$

where is the general mean of the characteristic.

Environmental correlations

$$
r_{a}=\frac{P M R_{x y}}{\sqrt{Q M R_{x} Q M R_{y}}} ;
$$

where $P M R$ is the mean product associated with the residue.

Genetic correlations

$$
r_{g}=\frac{\operatorname{COV}_{g x y}}{\sqrt{\hat{\sigma}_{g x}{ }^{2} \hat{\sigma}_{g y}{ }^{2}}}
$$

Gain by selection

$$
G S=D s \cdot h^{2} ; \quad \text { Ds }=\mathrm{Y}_{\mathrm{s}}-\mathrm{Y}_{\mathrm{o}}
$$

where Ds is the differential between families, $\mathrm{Y}_{\mathrm{s}}$ is the mean of selected families, and $\mathrm{Y}_{\mathrm{o}}$ is the mean of the base population. The selection gain calculation was performed based on the selected population where a value equal to $23 \%$ was used for the selection pressure of the population that was used in the next selection cycle.

The tests that were successful selected promising snap bean progenies with means compared using the Scott-Knott test at a $5 \%$ probability level.

\section{Results and Discussion}

The mean seed moisture content of the progenies was $7.9 \pm 0.4 \%$. The uniformity of the moisture content is an essential factor for standardizing the seed physiological quality evaluations (Marcos, 1999) so that the tests are not affected by differences in metabolic activity, wetting speed, and seed deterioration intensity (Coimbra, Martins, Thomas, \& Nakagawa, 2009; Dutra, \& Vieira, 2004; Marcos, Kikuti, \& Lima, 2009; Silva \& Martins, 2009).

The values of mean, mode, and median were similar within each progeny when evaluated for length, width, and thickness of the seed (Table 1). Progeny 5 had a lower mean length and mass compared to the other progenies; however the variables width and thickness of the seeds were not different from the other progenies. Progeny 10 had the highest mean length and mass of the seed progenies tested (Table 1). All the evaluated progenies and biometric variables presented low standard error; however, the major standard error was observed in the seed length measurements in the $1,2,10$, and 11 progenies. These results show that seed length is a parameter that interferes with the seed mass of snap bean progenies, in relation to seed size. 
Table 1

Descriptive statistics for variables: length $(\mathrm{L})$, width $(\mathrm{W})$, thickness $(\mathrm{T})$ of seeds of 13 progenies of snap bean. 1: MR malina; 2: Tender Green; 3: Haf 46; 4: Amarelo Japonês; 5: Napoli; 6: Delinel; 7: Red Provided; 8: Branco Japonês; 9: Commodose Improved; 10: Contender; 11: Jade; 12: Strike e 13: Espada Bush. *Data in melemeters. Iporá-GO

\begin{tabular}{|c|c|c|c|c|c|c|c|c|}
\hline Progenies & Variable* & Standard error & Mean & Mode & Median & Minimum & Maximum & Variance \\
\hline \multirow{3}{*}{1} & $\mathrm{~L}$ & $12.10 \pm 0.3$ & 12.10 & 12.00 & 12.00 & 10.60 & 14.00 & 4.75 \\
\hline & $\mathrm{W}$ & $6.38 \pm 0.1$ & 6.38 & 6.00 & 6.20 & 5.50 & 7.30 & 5.64 \\
\hline & $\mathrm{T}$ & $5.47 \pm 0.1$ & 5.47 & 6.00 & 5.25 & 4.50 & 7.00 & 7.68 \\
\hline \multirow{3}{*}{2} & $\mathrm{~L}$ & $13.83 \pm 0.3$ & 13.83 & 13.00 & 13.65 & 11.50 & 16.50 & 7.09 \\
\hline & W & $6.65 \pm 0.1$ & 6.65 & 6.50 & 6.50 & 6.00 & 8.00 & 5.56 \\
\hline & $\mathrm{T}$ & $6.10 \pm 0.2$ & 6.10 & 6.00 & 6.00 & 5.00 & 7.00 & 6.72 \\
\hline \multirow{3}{*}{3} & $\mathrm{~L}$ & $14.07 \pm 0.2$ & 14.07 & 14.00 & 14.00 & 12.30 & 16.00 & 3.91 \\
\hline & $\mathrm{W}$ & $6.28 \pm 0.1$ & 6.28 & 6.00 & 6.25 & 5.00 & 7. & 6.37 \\
\hline & $\mathrm{T}$ & $5.21 \pm 0.1$ & 5.21 & 5.00 & 5.00 & 4.50 & 6.00 & 5.18 \\
\hline \multirow{3}{*}{4} & $\mathrm{~L}$ & $12.70 \pm 0.2$ & 12.70 & 12.00 & 12.50 & 11.00 & 15.00 & 5.59 \\
\hline & W & $5.98 \pm 0.1$ & 5.98 & 6.00 & 6.00 & 5.00 & 7.00 & 5.85 \\
\hline & $\mathrm{T}$ & $5.13 \pm 0.1$ & 5.13 & 5.00 & 5.00 & 4.50 & 6.00 & 6.63 \\
\hline \multirow{3}{*}{5} & $\mathrm{~L}$ & $11.00 \pm 0.2$ & 11.00 & 11.00 & 11.00 & 10.00 & 13.00 & 3.91 \\
\hline & W & $5.26 \pm 0.1$ & 5.26 & 5.00 & 5.00 & 4.80 & 6.50 & 5.51 \\
\hline & $\mathrm{T}$ & $4.43 \pm 0.1$ & 4.43 & 4.00 & 4.50 & 4.00 & 5.50 & 7.67 \\
\hline \multirow{3}{*}{6} & $\mathrm{~L}$ & $13.63 \pm 0.2$ & 13.63 & 14.00 & 13.80 & 12.50 & 15.00 & 3.89 \\
\hline & W & $5.08 \pm 0.1$ & 5.08 & 5.00 & 5.00 & 4.00 & 6.00 & 4.53 \\
\hline & $\mathrm{T}$ & $4.82 \pm 0.1$ & 4.82 & 5.00 & 5.00 & 4.30 & 5.50 & 4.56 \\
\hline \multirow{3}{*}{7} & $\mathrm{~L}$ & $12.31 \pm 0.1$ & 12.31 & 12.00 & 12.00 & 10.00 & 14.00 & 5.85 \\
\hline & W & $5.46 \pm 0.1$ & 5.46 & 5.00 & 5.40 & 4.80 & 6.90 & 7.69 \\
\hline & $\mathrm{T}$ & $5.43 \pm 0.1$ & 5.43 & 5.00 & 5.50 & 4.80 & 6.20 & 6.81 \\
\hline \multirow{3}{*}{8} & $\mathrm{~L}$ & $12.48 \pm 0.1$ & 12.48 & 12.50 & 12.50 & 11.00 & 14.00 & 3.77 \\
\hline & $\mathrm{W}$ & $5.91 \pm 0.1$ & 5.91 & 6.00 & 6.00 & 4.50 & 7.00 & 5.58 \\
\hline & $\mathrm{T}$ & $5.16 \pm 0.1$ & 5.16 & 5.50 & 5.00 & 4.00 & 6.00 & 7.56 \\
\hline \multirow{3}{*}{9} & $\mathrm{~L}$ & $12.96 \pm 0.1$ & 12.96 & 13.00 & 13.00 & 11.50 & 14.00 & 4.40 \\
\hline & $\mathrm{W}$ & $5.55 \pm 0.1$ & 5.55 & 5.50 & 5.50 & 4.50 & 6.00 & 5.23 \\
\hline & $\mathrm{T}$ & $5.09 \pm 0.1$ & 5.09 & 5.00 & 5.00 & 4.00 & 6.00 & 5.30 \\
\hline \multirow{3}{*}{10} & $\mathrm{~L}$ & $16.32 \pm 0.3$ & 16.32 & 17.00 & 16.50 & 14.00 & 18.50 & 5.45 \\
\hline & $\mathrm{W}$ & $6.19 \pm 0.1$ & 6.19 & 6.00 & 6.00 & 5.50 & 7.50 & 6.79 \\
\hline & $\mathrm{T}$ & $5.45 \pm 0.2$ & 5.45 & 5.00 & 5.50 & 5.00 & 7.00 & 7.34 \\
\hline \multirow{3}{*}{11} & $\mathrm{~L}$ & $13.07 \pm 0.3$ & 13.07 & 12.50 & 13.00 & 11.50 & 15.00 & 5.89 \\
\hline & $\mathrm{W}$ & $5.75 \pm 0.1$ & 5.75 & 6.00 & 6.00 & 4.50 & 6.50 & 6.43 \\
\hline & $\mathrm{T}$ & $5.20 \pm 0.1$ & 5.20 & 5.00 & 5.00 & 4.00 & 6.00 & 5.96 \\
\hline \multirow{3}{*}{12} & $\mathrm{~L}$ & $11.97 \pm 0.1$ & 11.97 & 13.00 & 12.00 & 10.50 & 13.50 & 7.02 \\
\hline & $\mathrm{W}$ & $5.28 \pm 0.1$ & 5.28 & 5.00 & 5.00 & 5.00 & 6.50 & 5.49 \\
\hline & $\mathrm{T}$ & $5.09 \pm 0.1$ & 5.09 & 5.00 & 5.00 & 4.50 & 5.50 & 4.52 \\
\hline \multirow{3}{*}{13} & $\mathrm{~L}$ & $12.48 \pm 0.2$ & 12.48 & 12.50 & 12.50 & 11.50 & 14.00 & 3.29 \\
\hline & W & $5.60 \pm 0.1$ & 5.60 & 5.50 & 5.50 & 5.00 & 6.00 & 4.82 \\
\hline & $\mathrm{T}$ & $5.06 \pm 0.1$ & 5.06 & 5.00 & 5.00 & 4.50 & 6.00 & 3.56 \\
\hline
\end{tabular}


According to Rodrigues, Osuma, Queiroz and Rios (2006), a large variation observed in seed size is a common occurrence in polyspermy fruits. Due to competition, there is an interference in the final size of the seeds, with a reduction of seed size occurring most of the time. The smaller the seed size, the greater the production per individual (Dalling, Hebbell, \& Silveira, 1998). In addition, the large amplitudes between the maximum and minimum variable values within each progeny may be due to the influence of biotic and abiotic factors during flowering and development, even within the intrinsic factors of the species. According to Paiva, Viana, Santos, Freitas and Amaral (2016), the amplitudes may be indicative of the high genetic variability of a species, which is an acceptable variation in progeny research.
Significant differences were observed for all characteristics in the snap bean populations (Table 2 ). High coefficient values of the genetic variation among progenies suggest that there is a possibility of expressive gains during the selection for all evaluated characteristics. These characteristics are related to seed quality, germination, and vigor. Estimates of the genetic characteristics for heritability and the relationship between the coefficients of genetic and experimental variation reflected a favorable selection outcome because they ranged from 86.1 to $99.2 \%$ for heritability and 1.25 to 5.63 for the relationship between the genetic and experimental variation coefficients (Table 2).

\section{Table 2}

Summary of the analysis of variance and estimation of the genetic parameters for the tests of evaluation of seed of thirteen snap bean progenies. Thousand-seed weight (TSW, g); Germination test (G, \%); Classification of seedling vigor (CSV, \%); Seedling length (SL, cm); Seedlings dry mass (DM, mg.seedling-1); Emergence of seedlings in the field (ESF, \%) and Emergence speed index of seedlings in the field (ESI)

\begin{tabular}{|c|c|c|c|c|c|c|c|c|}
\hline \multirow{2}{*}{$\begin{array}{l}\text { Source of } \\
\text { variation }\end{array}$} & \multicolumn{8}{|c|}{ Mean square } \\
\hline & DF & TSW & G & $\mathrm{CSV}$ & SL & DM & ESF & ESI \\
\hline Progenies & 12 & $16802.91^{* *}$ & $999.74 * *$ & $645.08 * *$ & $34.82 * *$ & $6982.66^{* *}$ & $723.69 * *$ & $7.86^{* *}$ \\
\hline Residue & 39 & 131.54 & 97.74 & 75.69 & 2.46 & 390.06 & 100.51 & 0.41 \\
\hline Mean & & 319.18 & 70.54 & 38.46 & 22.45 & 187.41 & 66.61 & 3.32 \\
\hline $\mathrm{H}^{2}$ & & 99.22 & 90.22 & 88.27 & 92.92 & 94.41 & 86.11 & 94.8 \\
\hline $\mathrm{CVe}$ & & 3.59 & 14.02 & 22.62 & 6.99 & 10.54 & 15.05 & 19.22 \\
\hline $\mathrm{CVg}$ & & 20.23 & 21.29 & 31.02 & 12.67 & 21.66 & 18.73 & 41.05 \\
\hline $\mathrm{CVe} / \mathrm{CVg}$ & & 5.63 & 1.52 & 1.37 & 1.81 & 2.06 & 1.25 & 2.13 \\
\hline
\end{tabular}

**Significant at the $1 \%$ probability level by the $\mathrm{F}$ test; DF- degrees of freedom; $\mathrm{H}^{2}$ - heritability (\%); CVe - Coefficient of Variation experimental; CVg - Coefficient of Variation genetic

When the coefficients of genetic and experimental variation are greater than 1.0 , the genetic variation surpasses environmental variation (Vencovsky \& Barriga, 1992). Therefore, when the selection was conducted in the first year, it maximized the genetic gain, which decreased in the subsequent years. A larger value of $\mathrm{CVg} / \mathrm{CVe}(5.63)$ was observed for the thousand-seed weight, indicating that for a future selection with immediate genetic gains, this variable is more favorable. Although very promising values were observed for all evaluated variables. Therefore, it can be predicted that an increase in the mean of the selected characteristics will be almost equivalent to the differential of selection imposed on that 
characteristic because the values of the heritability coefficients ranged from $94.41-99.22 \%$ (Table 2).

Similar heritability results were observed in studies with: i) seeds from three cultivars and fourteen lineages of soybean that were selected for germination and seedling emergence in sandy soil from regions in Minas Gerais (Vasconcelos et al., 2012); ii) 94 bean lineages in relation to seed dry mass (Maia et al., 2011); iii) carrot half-siblings for the first germination count, germination, and accelerated aging tests (Martins et al., 2014); and iv) for forage turnip seeds in relation to germination, seedling vigor classification, accelerated aging test, seedling emergence in the field (S. S. C. Oliveira et al., 2014), and seedling emergence speed index in the field (S. S. C. Oliveira et al., 2017).

Genotypic correlations indicated that when selecting a characteristic, simultaneous genetic gains occurred in other correlated characteristics (Bueno, Mendes, \& Carvalho, 2006). Indeed, we observed that the snap bean progenies with the best seed performance characteristics, such as the thousand-seed weight, length, seedling dry mass, and emergence of the seedlings in the field can be used for selection (Table 3). In order to obtain genotypes with better seed performance in the field, evaluating both seedling emergence and dry mass can be performed in laboratory tests.

\section{Table 3}

Estimates of the coefficient of correlation genetic and coefficient of correlation environmental (above diagonal line: genetic correlation coefficient; below diagonal line: environmental correlation coefficient), for tests of quality evaluation of thirteen snap bean progenies, Iporá-GO. Thousand-seed weight (TSW. g), Germination test (G, \%), classification of seedling vigor (CSV, \%), seedling length (SL, cm), seedling dry mass (DM, mg.seedling ${ }^{-1}$ ), emergence of seedlings in the field (ESF, \%) and emergence speed index of seedlings in the field (ESI)

\begin{tabular}{cccccccccccccc}
\hline Characters & TSW & \multicolumn{2}{c}{ G } & \multicolumn{2}{c}{ CSV } & \multicolumn{2}{c}{ SL } & \multicolumn{2}{c}{ DM } & \multicolumn{2}{c}{ ESF } & \multicolumn{2}{c}{ ESI } \\
\hline TSW & -- & -0.13 & & -0.30 & $* *$ & 0.29 & $* *$ & 0.98 & $* *$ & 0.27 & $* *$ & -0.31 & $* *$ \\
G & 0.07 & -- & & 0.96 & $* *$ & 0.73 & $* *$ & -0.38 & $* *$ & 0.36 & $* *$ & -0.01 & \\
CSV & 0.02 & 0.68 & $* *$ & -- & & 0.72 & $* *$ & -0.50 & $* *$ & 0.38 & $* *$ & 0.12 & \\
SL & 0.07 & 0.32 & $* *$ & 0.49 & $* *$ & -- & & 0.12 & 0.65 & $* *$ & 0.12 & \\
DM & -0.08 & -0.32 & $* *$ & -0.21 & & -0.12 & & -- & 0.18 & -0.28 & $* *$ \\
ESF & 0.17 & -0.02 & & 0.04 & & 0.06 & -0.13 & -- & 0.54 & $* *$ \\
ESI & 0.16 & 0.00 & & 0.06 & & 0.01 & & -0.1 & 0.94 & -- & \\
\hline
\end{tabular}

** Significant at the $1 \%$ probability level by the $\mathrm{F}$ test.

For several species, seed weight is an indicator of physiological quality (Bezerra, Momenté, \& Medeiros, 2004) because a greater amount of reserves increases the probability of success of seedling establishment through promoting survival for a longer duration in adverse environmental conditions (Araldi et al., 2013). Thus, superior genotypes should be selected for a set of favorable characteristics where the performance of the seeds is the main factor in the release of new cultivars.
This selection depends on the performance of the seeds under both field and storage conditions, and the acceptance of the cultivar by the agricultural market (Martins et al., 2014). The emergence of seedling tests in the field is fundamental because it includes diverse climatic conditions that the success in which the initial establishment of the plants will be analyzed (Coimbra et al., 2009; Silva, \& Martins, 2009; Vasconcelos et al., 2012). 
The estimates of genetic gain, initial means of the selected population, and improved mean are presented in Table 4 and allow for the establishment of genetic selection gains in all the evaluated tests, although they are less expressive for the length of seedlings. The lower genetic gains are associated with more complex characteristics of gene control.
The mean length of the normal seedlings was determined assuming the samples that expressed the highest values are the most vigorous, this is because the more vigorous seeds produce seedlings with higher growth rates due to the greater translocation of reserves from storage tissues to the growth of the embryonic axis (Nakagawa, 1999).

\section{Table 4}

Estimates of mean genetic gains by selection (GS) and the initial mean of the selected population to the evaluated tests of quality of seed in thirteen span bean progenies, Iporá - GO. Initial means of the population ( $\mu$ i), $23 \%$ from selected population ( $\mu \mathrm{s})$, and breeding mean $(\mu \mathrm{m})$. Thousand-seed weight (TSW. g), Germination test (G, $\%$ ), classification of seedling vigor (CSV, \%), seedling length (SL, cm), seedling dry mass (DM, mg.seedling $\left.{ }^{-1}\right)$, emergence of seedlings in the field (ESF, \%) and emergence speed index of seedlings in the field (ESI)

\begin{tabular}{cccccc}
\hline & \multicolumn{2}{c}{ Genetic gain } & \multicolumn{3}{c}{ Means } \\
\hline Characters & GS & $\%$ & $\mu \mathrm{i}$ & $\mu \mathrm{s}$ & $\mu \mathrm{m}$ \\
\hline TSW & 84.22 & 26.39 & 319.18 & 404.25 & 403.40 \\
G & 13.61 & 19.29 & 70.54 & 85.67 & 84.15 \\
CSV & 11.62 & 30.21 & 38.46 & 51.67 & 50.08 \\
SL & 2.38 & 10.60 & 22.45 & 25.01 & 24.83 \\
DM & 52.2 & 27.85 & 187.41 & 242.95 & 239.61 \\
ESF & 14.37 & 21.57 & 66.62 & 83.33 & 80.99 \\
ESI & 1.79 & 53.75 & 3.33 & 5.21 & 5.12 \\
\hline
\end{tabular}

The genetic gain obtained for the classification of seedling vigor and emergence speed index of seedlings in the field was higher than $30 \%$ and $50 \%$, respectively, (Table 4). The initial mean population for the classification of seedling vigor and emergence speed index in the field was $38 \%$ and $67 \%$, respectively. After selection, the breeding population estimate increased to $50 \%$ and $81 \%$, respectively. Hence, the continuity of this breeding program will enable the production of snap beans with higher physiological quality and greater vigor and emergence speed in the field.

Understanding the physiological quality of the seeds assists in several aspects that promote the success of crop implantation and therefore, seedling vigor and emergence speed index under field conditions is important for understanding their development and ability to break the soil layer, as well as producing seedlings that are less susceptible to environmental variation, especially in relation to water availability.

These tests were chosen because of their high heritability (Table 2) and positive correlate with seedling emergence in the field (Table 3). Through these tests, it was possible to define the snap bean progenies that would be used in the next breeding program selection cycle. The more efficient tests were: i) germination, ii) classification of seedling vigor, iii) seedling emergence in the field, and iv) seedling emergence speed index in the field. Higher heritability coefficients provided greater genetic progress with selection and in turn, genetic correlation values have been applied to guide breeding programs because they reflect the fraction 
of phenotypic expression that is inheritable in Thus, progenies 5,8, and 13 were used for the next nature (Alves, Peixoto, Vieira, \& Boiteux, 2006). selection cycle, with a minimum amount of $23 \%$ Regarding the analyses of the means obtained for of available populations considered as appropriate the evaluated tests, the maximum performance to ensure the diversity of the genetic basis of the in the test was considered high vigor (Table 5). breeding program.

\section{Table 5}

Comparison of means for the percentage of germination (G), classification of seedling vigor (CSV), emergence of seedlings in the field (ESF) and emergence speed index of seedlings in the field (ESI), in thirteen snap bean progenies 1: MR malina; 2: Tender Green; 3: Haf 46; 4: Amarelo Japonês; 5: Napoli; 6: Delinel; 7: Red Provided; 8: Branco Japonês; 9: Commodose Improved; 10: Contender; 11: Jade; 12: Strike e 13: Espada Bush

\begin{tabular}{|c|c|c|}
\hline Progeny & $\mathrm{G}$ & Class of vigor \\
\hline 4 & $86.0 \mathrm{a}$ & High \\
\hline 13 & $85.3 \mathrm{a}$ & High \\
\hline 1 & $84.0 \mathrm{a}$ & High \\
\hline 6 & $82.0 \mathrm{a}$ & High \\
\hline 7 & $79.0 \mathrm{a}$ & High \\
\hline 8 & $79.0 \mathrm{a}$ & High \\
\hline 3 & $75.0 \mathrm{a}$ & High \\
\hline 5 & $74.0 \mathrm{a}$ & High \\
\hline 11 & $64.0 \mathrm{~b}$ & Medium \\
\hline 9 & $63.0 \mathrm{~b}$ & Medium \\
\hline 2 & $60.0 \mathrm{~b}$ & Medium \\
\hline 10 & $51.0 \mathrm{~b}$ & Medium \\
\hline 12 & $33.0 \mathrm{c}$ & Low \\
\hline Progeny & $\mathrm{CSV}$ & Class of vigor \\
\hline 4 & $53.0 \mathrm{a}$ & High \\
\hline 1 & $51.0 \mathrm{a}$ & High \\
\hline 8 & $51.0 \mathrm{a}$ & High \\
\hline 5 & $50.0 \mathrm{a}$ & High \\
\hline 13 & $46.7 \mathrm{a}$ & High \\
\hline 6 & $46.0 \mathrm{a}$ & High \\
\hline 7 & $41.0 \mathrm{a}$ & High \\
\hline 3 & $33.0 \mathrm{~b}$ & Medium \\
\hline 9 & $33.0 \mathrm{~b}$ & Medium \\
\hline 11 & $31.0 \mathrm{~b}$ & Medium \\
\hline 2 & $30.0 \mathrm{~b}$ & Medium \\
\hline 10 & $21.0 \mathrm{c}$ & Low \\
\hline 12 & $13.0 \mathrm{c}$ & Low \\
\hline Progeny & ESF & Class of vigor \\
\hline 10 & $90.0 \mathrm{a}$ & High \\
\hline 13 & $85.3 \mathrm{a}$ & High \\
\hline
\end{tabular}


continuation

\begin{tabular}{ccc}
8 & $74.0 \mathrm{~b}$ & High medium \\
5 & $72.0 \mathrm{~b}$ & High medium \\
4 & $70.0 \mathrm{~b}$ & High medium \\
1 & $70.0 \mathrm{~b}$ & High medium \\
7 & $68.0 \mathrm{~b}$ & High medium \\
9 & $66.0 \mathrm{~b}$ & High medium \\
2 & $62.0 \mathrm{c}$ & Low medium \\
6 & $62.0 \mathrm{c}$ & Low medium \\
3 & $56.0 \mathrm{c}$ & Low medium \\
12 & $50.0 \mathrm{~d}$ & Low \\
11 & $40.0 \mathrm{~d}$ & Low \\
\hline Progeny & ESI & Class of vigor \\
13 & $6.0 \mathrm{a}$ & High \\
5 & $5.0 \mathrm{~b}$ & High medium \\
8 & $4.7 \mathrm{~b}$ & High medium \\
10 & $4.5 \mathrm{~b}$ & High medium \\
9 & $3.9 \mathrm{~b}$ & High medium \\
12 & $3.5 \mathrm{c}$ & Low medium \\
6 & $3.2 \mathrm{c}$ & Low medium \\
11 & $2.7 \mathrm{c}$ & Low medium \\
4 & $2.3 \mathrm{~d}$ & Low \\
7 & $2.1 \mathrm{~d}$ & Low \\
1 & $2.1 \mathrm{~d}$ & Low \\
2 & $1.7 \mathrm{~d}$ & Low \\
3 & $1.6 \mathrm{~d}$ & Low \\
\hline
\end{tabular}

Mean followed by the same letter does not differ significantly by the Scott-Knott test at a $5 \%$ probability level.

When a characteristic is controlled by several genes, which is very common for most traits of economic value, the probability of all favorable alleles being associated with an individual is very small. Therefore, the chance of success increases with the number of families assessed and as a result, breeders often evaluate many families (Ramalho, Ferreira, \& Oliveira, 2012). Knowledge of the genetic parameters associated with these characteristics in snap bean populations will establish more effective breeding strategies for macro-regions with more uniform environmental conditions and high temperatures, such as the
Brazilian Savanna (Cerrado). Thus, the strategy for the selection of snap bean progenies with greater vigor would start in a new crossing cycle (recombination) using the three progenies chosen for high germination and vigor, with subsequent evaluation and selection for these factors in the field. In this way, to proceed with the selection of snap bean progenies with greater vigor, we start a new crossing cycle (recombination) using the three progenies chosen with the aid of germination and vigor tests, with subsequent evaluation and selection in the field. 


\section{Conclusions}

The genetic variability of snap bean characteristics we evaluated indicated that genetic breeding can significantly contribute to improving the physiological quality of snap bean seeds.

The germination test, classification of seedling vigor, emergence, and emergence speed index of seedlings in the field can be used to delineate selection strategies for snap bean populations that produce seeds with high vigor.

\section{Acknowledgments}

The authors thank the Federal Institute Goiano, Iporá, for providing all the necessary infrastructure for carrying out the experiments.

\section{References}

Alves, J. C. S., Peixoto, J. V., Vieira, L. S., \& Boiteux, L. S. (2006). Herdabilidade e correlações genéticas entre caracteres de folhagem e sistema radicular em famílias de cenoura, cultivar Brasília. Horticultura Brasileira, 24(3), 363-367. doi: 10.1590/S010205362006000300019

Araldi, R., Velini, E. D., Gomes, G. L. G. C., Carbonari, C. A., Alves, E., \& Trindade, M. L. B. (2013). Variação do tamanho de sementes de plantas daninhas e sua influência nos padrões de emergência das plântulas. Planta Daninha, 31(1), 117-126. doi: 10.1590/ S0100-83582013000100013

Bezerra, A. M. E., Momenté, V. G., \& Medeiros, S., F (2004). Germinação de sementes e desenvolvimento de plântulas de moringa (Moringa oleifera Lam.) em função do peso da semente e do tipo de substrato. Horticultura Brasileira, 22(2), 295-299. doi: 10.1590/S0102-05362004000200026

Ministério da Agricultura e Reforma Agrária (2009). Regras para análise de sementes. Brasília: SNDA/ DNDV/CLAV.

Bueno, L. C. S., Mendes. A. N. G., \& Carvalho, S. P. (2006). Melhoramento genético de plantas: principios e procedimentos. Lavras: UFLA.

Centrais de Abastecimento do Estado do Rio de Janeiro (2010). Consultas / cotação. Recuperado de http:// www,ceasa,rj,gov,br/ceasa/consultas/consultas,htm
Coimbra, R.A., Martins, C.C., Tomaz, C.A., \& Nakagawa, J. (2009). Testes de vigor utilizados na avaliação da qualidade fisiológica de lotes de sementes de milhodoce (sh2). Ciência Rural, 39(9), 2402-2408. doi: 10.1590/S0103-84782009000900004

Cruz, C. D. (2001). Programa Genes-Versão Windows: aplicativo computacional em genética e estatística. Viçosa: UFV.

Dalling, J. W., Hebbell, S. P., \& Silvera, K. (1998). Seed dispersal. seedling establishment and gap partitioning among tropical pioneer trees. Journal of Ecology, 86(4), 674-689. doi: 10.1046/j.13652745.1998.00298.x

Dutra, A. S., \& Vieira, R. D. (2004). Envelhecimento acelerado como teste de vigor para sementes de milho e soja. Ciência Rural, 34(3), 715-721. doi: $10.1590 / \mathrm{S} 0103-84782004000300010$

Food and Agriculture Organization (2018). FAOSTAT. Crops. Cow peas, dry. Retrieved from http://www.f ao.org/faostat/en/\#data/QC

Krause, W., Rodrigues, R., \& Leal, N. R. (2012). Capacidade combinatória para características agronômicas em feijão-de-vagem. Revista Ciência Agronômica, 43(3), 522-531. doi: 10.1590/s180666902012000300015

Maguire, J. D. (1962). Speed of germination-aid in selection and evaluation for seedling emergence and vigor. Crop Science, 2(1), 176-177. doi: 10.2135/cro psci1962.0011183X000200020033x

Maia, L. G. S., Silva, C. A., Ramalho, M. A. P., \& Abreu, A. F. B. (2011). Variabilidade genética associada à germinação e vigor de sementes de linhagens de feijoeiro comum. Ciência e Agrotecnologia, 35(2), 361-367. doi: 10.1590/S1413-70542011000200018

Mambrin, R. B., Ribeiro, N. D., Henning, L. M. M., Henning, F. A. \& Bokert, K. A. (2015). Seleção de linhagens de feijão com base no padrão e na qualidade de sementes. Revista Caatinga, 28(3), 147-156. doi: 10.1590/1983-21252015v28n317rc

Marcos, J., Fo. (1999). Teste de envelhecimento acelerado. In F. C. Krzyzanowski, R. D Vieira, \& J. B. França-Neto (Eds.), Vigor de sementes conceitos e testes (pp. 3.1-3.24). Londrina, PR: ABRATES.

Marcos, J., Fº, Kikuti, A. L. P., \& Lima, L. B. D. (2009). Métodos para avaliação do vigor de sementes de soja. incluindo a análise computadorizada de imagens. Revista Brasileira de Sementes, 31(1), 102-112. doi: 10.1590/S0101-31222009000100012 
Martins, C. C., Silva, N., \& Machado, C. G. (2014). Testes para a seleção de populações de cenoura visando ao vigor e à longevidade das sementes. Ciência Rural, 44(5), 768-775. doi: 10.1590/S010384782014005000001

Martins, C. C., Unêda-Trevisoli, S. H., Vitti Môro, G., \& Vieira, R. D. (2016). Metodologia para seleção de linhagens de soja visando germinação, vigor e emergência em campo. Revista Ciência Agronômica, 47(3), 455-461. http://www.ccarevista.ufc.br/seer/ index.php/ccarevista/article/view/4151/1411

Matos, M. J. L. F. (2010). Feijão-de-vagem: dicas ao consumidor. Brasília/Anápolis: EMBRAPA. Recuperado de http://www.cnph.embrapa.br/ paginas/dicas_ao_consumidor/feijao_de_vagem. htm

Nakagawa, J. (1999). Testes de vigor baseados no desempenho das plântulas. In: F. C. Krzyzanowski, R. D Vieira, \& J. B. França-Neto (Eds.), Vigor de sementes: conceitos e testes (pp. 2.1-2.24). Londrina: ABRATES.

Oliveira, A. P., Tavares Sobrinho, J., \& Souza, A. P. (2003). Característica e rendimento do feijãovagem em função de doses e formas de aplicação de nitrogênio. Ciência e Agrotecnologia, 27(3), 714720. doi: 10.1590/S1413-70542003000300030

Oliveira, S. S. C., Martins, C. C., Cruz, S. J. S., \& Silva, C. J. (2014). Seleção de progênies de nabo forrageiro para germinação sob altas temperaturas. Ciência Rural, 44(2), 217-222. doi: 10.1590/S010384782014000200004

Oliveira, S. S. C., Pereira, F. E. C. B., Lopes, M. T. G., \& Torres, S. B. (2017). Tests for the selection of forage turnip progeny to order the vigor and longevity of seeds. Revista Caatinga, 30(1), 230-236. doi: 10.1590/1983-21252017v30n125rc
Paiva, C. L., Viana, A. P., Santos, E. A., Freitas, J. C. O. \& Amaral Jr. (2016). Genetic gain estimated by different selection criteria in guava progênies. Bragantia, 75(4), 418-427. doi: 10.1590/16784499.477

Peixoto, N., Moraes, E. A., Monteiro, J. D., \& Thung, M. D. T. (2001). Seleção de linhagens de feijão-vagem de crescimento indeterminado para cultivo no Estado de Goiás. Horticultura Brasileira, 19(1), 85-88. doi: 10.1590/S0102-05362001000100018

Ramalho, M. A. P., Ferreira, D. F., \& Oliveira, A. C. (2012). Experimentação em genética e melhoramento de plantas. Lavras: UFLA.

Rodrigues, A. C. C., Osuma, J. T. A., Queiroz, S. R. O. D., \& Rios, A. P. S. (2006). Biometria de frutos e sementes e grau de umidade de sementes de angico (Anadenanthera colubrina (Vell.) Brenan var. Cebil (Griseb.) Altschul) procedentes de duas áreas distintas. Revista Cientifica Eletrônica de Engenharia Florestal, 4(8), 1-15. http://faef. revista.inf.br/imagens_arquivos/arquivos_destaque/ kSbm7OyS25h0O Gk_2013-4-26-10-50-41.pdf

Silva, L. B., \& Martins, C. C. (2009). Teste de condutividade elétrica para sementes de mamoneira. Semina: Ciências Agrárias, 30 (1), 1043-1050. http:// www.uel.br/revistas/uel/index.php/semagrarias/ article/ download/4640/3946.

Vasconcelos, E. S., Reis, M. S., Sediyama, T., \& Cruz, C. D. (2012). Estimativas de parâmetros genéticos da qualidade fisiológica de sementes de genótipos de soja produzidas em diferentes regiões de Minas Gerais. Semina: Ciências Agrárias, 33(1), 65-76. doi: 10.5433/1679-0359.2012v33n1p65

Vencovsky, R., \& Barriga, P. (1992) Genética biométrica no fitomelhoramento. Ribeirão Preto: Sociedade Brasileira de Genética. 